\title{
Exploring Corporate Social Responsibility in a Social Business: The Workers Beer Company
}

\author{
Alex Murdock*, Nick Dolezal ${ }^{* *}$
}

\begin{abstract}
The Workers Beer Company is a long-established company owned by the Battersea and Wandsworth Trades Union Council in London. The Trade Council is an umbrella group bringing together trade union branches in South London to promote trade union activity and membership locally. The Company's focus is to raise funds for 'left' organisations, promote trade union membership and support organisations to deliver ethical services through mobilising its volunteer base to run bars and sell drinks music festivals. Once costs are met company surpluses are either reinvested or are devoted to social purposes. This paper explores integrated CSR through a case study of an organisation that has provided support for the last 30 years at globally recognised festivals, developed ethical businesses and donated millions of pounds to good causes. The case study will use Glastonbury Festival as a focus for the legal, local government and environmental pressures that influence corporate behaviour and promote CSR.
\end{abstract}

Keywords: Integrated Corporate Social Responsibility; Stakeholders; Global Markets; The Workers Beer Company; Glastonbury Festival

\section{Integrated Corporate Social Responsibility}

Arguably a timely opportunity for this paper. Corporate Social Responsibility (CSR) and its place in contemporary thinking has rarely taken such prominence. (Lins et al 2017). Media headlines in the UK during Autumn of 2017 were dominated by stories of corporate irresponsibility and of individuals acting irresponsibly, often with profound consequences. The Paradise Papers have led to the widespread reporting of organisations, government bodies, members of the British aristocracy as well as the United Kingdom Royal Family using off shore tax havens to maximise their investments with a hint of something not quite right and a suggestion of acting amorally. ${ }^{i}$ As well as financial impropriety, there have been the far more serious consequences of individuals in leading positions in organisations denying workers and others their human basic rights and abusing them for their own gratification or own advancement. There have been media reports of leading members of both the British government and global entertainment organisations abusing their positions unethically; in the entertainment world stories of Harvey Weinstein's abuses featured

\footnotetext{
* Professor Emeritus, London South Bank University (alex.murdock@1sbu.ac.uk)

*** Research Fellow, London South Bank University (nick.dolezal@southwark.gov.uk)
}

Edited by: University of Milan-Bicocca

ISSN: 1593-0319

Murdock, A., \& Dolezal, N. (2018). Exploring Corporate Social Responsibility in a Social Business: The Workers Beer Company. Symphonya. Emerging Issues in Management (symphonya.unimib.it), 1, 91-103. 
in the media for weeks. And, in the world of politics accusations of leading members of the United Kingdom Parliament taking advantage of staff, including allegations of rape, have appeared regularly in the UK media.

It was only in the 1950s that CSR formally entered the business lexicon, when the firm became a component of social equilibrium. Moving on, CSR has excited businesses, governments and academics ever since the concept crept into everyday language in the 1960s as a way to describe corporate activities that have ethical and accountable approaches to the world in which they operate (Ruggle 2017). It is not surprising that over the last 50 or so years the language used to describe and underpin CSR has moved on and given rise to questions as to whether day to day corporate activity now marries up to organisations acting responsibly, implement the CSR in companies' strategies has become very important (Brondoni, 2010).

Arguably, approaches have matured from a simplistic model of philanthropy and paying for beneficial outcomes through donations to adjusting corporate behaviour to minimise harmful impacts on the immediate zone of activity. To ensure that the corporate activity can create value and contribute to all its stakeholders' environmental, cultural or social well-being. Public opinion, driven through exposure by the media and the speed of social media, has increased the pressure on organisations to become more aware of the impact they have on their surrounding and their stakeholders (Brondoni, 2010). In turn this has reinforced the theory of CSR to ensure that organisations should take account of the harm they may cause, rectify it and contribute some measurable benefit back into the community. Business practice and opinion has consequently had to advance as well, debatably a wellmeaning approach to CSR to mitigate corporate activity delivered to communities without the communities' involvement is no longer seen to be a sustainable way forward. Public opinion and evolving attitudes to sustainable business has reignited the need to place CSR in a modern academic, legal, governmental (at all levels) and financial framework that responds to current and future expectations linked to minimising harms and maximising benefits accruing to corporate activity. The debates about CSR have been married to a parallel criminological discussion about the impact of corporations on our everyday living and the potentially harmful consequences of their activities. Much of this has focused on the rapidly increasing influence of 'global' corporations and the hidden nature of corporate crime, the discussion has argued that crime occurs throughout society and that that least powerful are the most vulnerable to the effects of corporate irresponsibility. Many of the social harms created by corporate irresponsibility can have dramatic if not fatal consequences for those concerned, pensions lost, market prices rigged, death due to poor health and safety on building sites, exposure to asbestos, contaminated water, air born pollution and food poisoning amongst the risks ( Pegg \& Zabbey 2013).

An alternative approach to CSR touches on a possible shift in understanding the relationships between business, society, and the environment. It will use the case study of a long established not for profit organisation, the Workers Beer Company, to look at how ethics, stakeholders and creating value can combine to underpin a successful commercial organisation. In using a case study the paper will draw on empirical evidence to inform process, practice and strategic positioning. It is hoped that the discussions that emerge from the case study will go on to inform the current theoretical debate exploring the shortcomings of traditional approaches to CSR and 
the potential of the emerging interpretation of CSR and its integration into the corporate body.

It will start with some simple definitions, explore the economic, social and environmental components as well as look at the influences that are brought to bear on understanding CSR.

\section{The Corporation}

Debatably, corporations had a rocky start. The corporation is a relatively modernday construct born out of the seventeenth century English joint stock companies that set out to colonise the Americas and India. 'Those companies (such as the Virginia Company and the British East India Company) allowed the wealth of several people to be combined and brought under the name of one entity' (Tombs and Whyte 2010).

Tombs and Whyte go on to describe that by the late nineteenth century these early vehicles for investors became limited liability companies, which allowed their stakeholders to share the profits of their investment while limiting their liabilities to their original investment or share. A corporation became a legal identity which makes money; has shareholders, stakeholders, employees, investors and customers. As a legal form it has economic, environmental and social power; it has the political influence to protect itself. It is designed to deliver the benefits for the corporation while protecting the corporation from the consequences of any harm it might cause. In the beginning, it could be said that the overwhelming objective of the corporation was to protect its overseas interests of a colonial past regardless of the harm it caused.

In 2004, Freeman et al, in Stakeholder Theory and "The Corporate Objective Revisited" discussed that for corporations economic and political freedom are inseparable and that 'Value creation and trade have to go together. One is no good without the other.' (Freeman et al, 2004). In making this argument they build the case that to distinguish between shareholders and stakeholders creates an artificial distinction that does not advance the case for corporate social responsibility; primarily, because classic shareholder theory promotes the concept '... of business as an amoral economic activity that radically constricts what is possible for human beings.' (Freeman et al, 2004). In challenging this notion of shareholder theory, they establish that shareholders and stakeholders should not be considered as different management entities in management theory but one and the same. Once taking this step, they go on to argue that that corporations should consider the nature of the 'moral content' of the organisation as it helps all the participants to understand the shared purpose of the company and how value is created and traded by that company.

Bringing the idea that corporations have economic, environmental and social power together with the view that corporations should have a 'moral content' to creating and trading value highlights that they will be judged on whether they act responsibly or not; whether the harm they cause as an organisation and the products they make or the services they provide outweighs the benefits of those product or services. In this simple form ideas of corporate social responsibility begin to take hold and that organisations should act in such a way that mitigates harm and emphasises any benefits across the spectrum of stakeholders involved - shareholders, investors, employees, customers and communities. Possibly, there is a management theory case to reduce the discussion to a simple binary of corporate social 
responsibility in contrast to corporate social irresponsibility; in doing so attempt to avoid having fruitless disagreements about the shades of grey that exist between the academic exchanges about the best way to create value, the most efficient ways to trade and which one of the many stakeholders' rights are dominant over the other as Freeman et al say ' .... are all intellectual moves that serve neither truth nor freedom' (Freeman et al, 2004).

Having introduced the ideas of CSR and the stakeholders the paper draws on the definitions used by the United Nations Industrial Development Organization (UNIDO), the agency formed in 2013 to promote CSR in the member states. UNIDO has advanced a distinction between CSR as a strategic management concept and philanthropy. It promotes CSR as having the following key components 'environmental management, eco-efficiency, responsible sourcing, stakeholder engagement, labour standards and working conditions, employee and community relations, social equity, gender balance, human rights, good governance, and anticorruption measures' (UNIDO, 2013). UNIDO has also mapped out the stakeholders an organisation might engage with which helps identify key players and their specific interests.

Figure 1: Economic, Social and Environmental Performance Issues

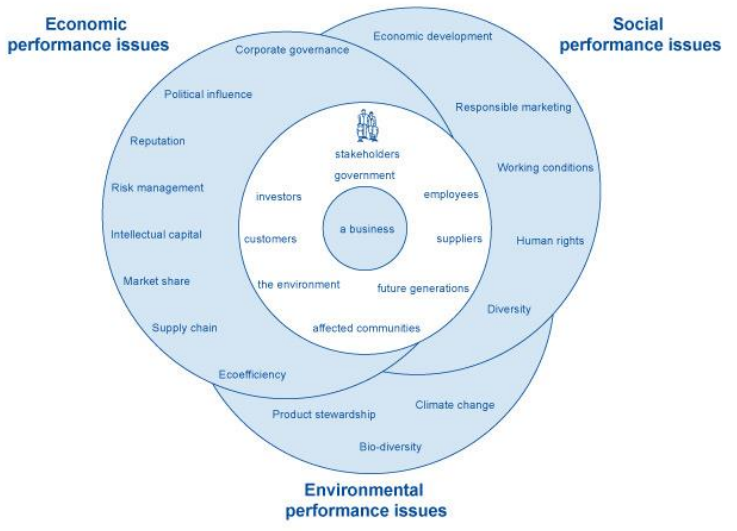

As discussed earlier, CSR should not be considered an entirely new phenomenon; for example English industrialists in the late $19^{\text {th }}$ century were building homes for their work force in a way that began to go beyond simple philanthropy and attempted not only to provide proper homes but also decent work conditions as well as education, leisure and recreation facilities, for example the Lever Brothers in their Port Sunlight soap making factory in Liverpool with its model village to house their workers with an underlying objective to make 'life pleasant' for their employees. At around the same time George Bernard Shaw, when he was a London councillor in 1904, was grappling with the massive environmental and social harm the railway companies were causing as they build their way into the heart of London. As a consequence of his experience he toyed with ideas of municipal trading 'The question whether municipal trading is sound in principle cannot be settled by the figures if this or that adventure in it, any more than the soundness banking or insurance can be settled by the figures of this or that big dividend or disastrous liquidation. Besides, the balance sheet of a city's welfare cannot be stated in figures. Counters of a more spiritual kind are needed, and some imagination and conscience to add to them as 
well' (Shaw, 1904) where he quite clearly challenges the 'bottom line' approach of measuring corporate success in profit alone. In 1904 local government was rising to the challenge of providing gas, electricity, clean water, sanitation transforming cities, towns and villages into the places we recognize now and laying the foundations for many modern-day corporations we identify today in their privatized form. At the time, he was arguing for the landowners and the railways to recognise their corporate responsibility and meet their obligations to rehouse those evicted and displaced by the massive programme of railway and station building of the day. At the beginning of the $20^{\text {th }}$ century the Lever Brothers and George Bernard Shaw both recognised that people should lead pleasant lives and that they should feel spiritually uplifted that there are moral and ethical dimensions to peoples' well-being and it was an important outcome for corporate interests to pursue.

In 2013 McKinsey and Company challenged traditional CSR and dramatically concluded that it was ' ... failing to deliver, for both companies and society' (Browne and Nuttall, 2013) and go on to raise the challenge in terms of whether integrated external engagement would be a thing of the future. They argue that one of the key disappointments of traditional CSR is that is has failed organisations in building stronger relationships with the external world. It goes onto suggest that chief executives are regularly cast as villains of the peace with the impact of the 2008 financial crisis or BP polluting the Gulf of Mexico still reverberating around the media and social media worlds. They propose organisations should adopt an integrated approach to CSR to ensure that organisations engage with their stakeholders early enough to build trust, to allay fears that CSR is just a propaganda exercise and to identify common objectives for stakeholders and competitors can agree on and act collaboratively to deliver mutually beneficial objectives. The importance of CSR in terms of consumer perception is a clear factor and this is important in terms of supply chain arrangements (Musso \& Risso 2006).

To recap, this paper explores some of these emerging concepts of CSR through a case study of a social enterprise organisation, The Workers Beer Company, that recently celebrated 30 years of selling drinks at globally recognised festivals, promoting festivals across Europe, developing ethical businesses and donating millions of pounds to trade union and broadly left-wing causes. The case study will use Glastonbury Festival to draw out some of the pressures that influence corporate behaviour and promote CSR. The approach taken will touch on the corporate governance, management and organisational strategy of the organisation and its delivery of commercial competence, environmental sustainability and social awareness. The case study comes in two parts. The first part will be an internal examination of the organisation, how it came about and the CSR objectives it has adopted. The second part will be an external view of the organisation works and the services it provides in running bars at Glastonbury, which in turn has its own CSR objectives. In both parts, the discussion will touch upon the economic, social and environmental influences in play.

The discussion about the future of CSR must, in some part, explore the issues of 'corporate choice'; how it chooses the organisation's structure, how the organisation chooses to engage with its world, how it chooses to treat its employees, how it chooses to treat it customers and how it chooses to create value. The nature of these choices typically will involve partnerships and, in the context of the Workers Beer Company, aspects of social innovation (Risso 2012). 
The Battersea and Wandsworth Trades Council chose the values that the Workers Beer Company (WBC) should aim for, they were born out of the trade union movement as a response to the election of the Thatcher Conservative government in 1979. The trades council decided that the unions would be for the long haul of campaigning, marching and protesting against the government's economic and social policy of destroying the unions and cutting public sector spending. The WBC emerged out a free concert on Clapham Common, in London, to bring together likeminded people to campaign against the attacks on the unions and to have some fun as well - to do something spiritually uplifting. In this light, the organisation adopted the rallying call of the early American trade union movement from a speech by the trade union activist Rose Schneiderman 'The worker must have bread, but she must have roses, too. ${ }^{\text {ii }}$ Which underpins the sentiment that workers should be able to hope for more than just a living wage but have the right to expect a reasonable quality of life as well. This carries through today in the naming of the bars, the pub and bringing together of left-wing political campaigning and music festivals.

It is not surprising that from 1986 the WBC started running the bars at the Glastonbury Festival of Contemporary Performing Arts run by Michael Eavis at his Worthy Farm, Pilton in Somerset. The WBC was recommended to Michael by the manager of the events run by the left-wing Ken Livingstone's Greater London Council campaign for Jobs in the 1980s. Michael had already promoted his manifesto for Glastonbury 'Man is fast ruining his environment, he is suffering from the effects of pollution; from the neurosis brought about by a basically urban industrial society; from a lack of spirituality in his life; and a spiritual awakening' Glastonbury Fair Manifesto 1971, (Bailey, 2013) and it resonated with the values of the WBC of combining an ethical approach to a spiritually uplifting enterprise - and the rest is history, bands, performance and fun. While Glastonbury Festival is a global brand and the WBC is one of the leading festival bar operators in the UK in Ireland the experience they have shared and the focus of this paper in not 'that everyone can or wants to do what they have done' but more if everyone thought a bit more about the choices they make about acting responsibly as an organisation CSR may have a brighter future. One last thing, not everything Glastonbury and the WBC have done has been perfect - that would be nonsensical.

\section{The Workers Beer Company}

The WBC is a not for profit social enterprise and its main focus is selling drinks in industrial quantities to masses of festival goers in the UK and Ireland. It is one of the leading and probably one of the longest lasting providers of these services. Since it was formed it has sold drinks at some of the best-known festivals in the UK and Ireland if not the world; Glastonbury, Reading, Leeds, The Fleadh, Latitude, Longitude, Benecassim, 2012 Olympics, Wireless, Marlay Park, Slane Castle, Womad and the list goes on to include 50 further festivals or events the company has worked at including Nelson Mandela's $70^{\text {th }}$ birthday party.

Just to get a simple question out of the way; is selling alcohol socially responsible?

For some the answer will be no - but for many buying drinks at festivals is an expectation they have to be able to lead a culturally enriched life adding to their spiritual well-being. The first and obvious starting point is that selling alcohol and 
promoting festivals and events is legal and highly regulated. The WBC works within the law and fully complies with the statutory regulations and promotes responsible drinking. The WBC works well with local authorities who heavily enforce their licensing conditions at festivals to ensure that all the suppliers act responsibly and cause no harm. The WBC is well respected in the drinks industry by the licensing authorities that recognise that it promotes a responsible approach to selling alcohol in a safe environment. It is appreciated and trusted by the promoters who put on the events and the other contractors and suppliers it has to work alongside.

The origins of the WBC can be traced back in time and its political roots to 1980s. The owners of WBC, the Battersea and Wandsworth Trades Union Council (BWTUC), were discussing how it should respond to (UK Conservative Prime Minister) Margaret Thatcher's first year in power and the attacks she had made on the trade union movement, particularly public services. The meeting concluded that 'The consensus was that the unions should be prepared for a long haul and that marching and protests would not be enough to get a change of course in government economic and social policy. It was decided to stage a free concert on Clapham Common to rally the anti-Tory forces in the area for a day of fun and politics.' (Brown et al, 2016). Clearly setting out its stall with regard to the economic, social and environmental objectives in the framework of doing something that is spiritually uplifting, fun - very much in keeping with the sentiments held dear by Schneiderman in her speech associated with the 1912 striking women textile workers in the United States 'The worker must have bread, but she must have roses, too.' ( see earlier footnote). WBC is an organisation that chose to have a strong political focus and chose to create value through selling drink and staging popular events.

Later, in $1985 \mathrm{WBC}$ was set up as a trading company to raise funds for the BTWUC. Its CSR objectives emerged and are to support the trade union or left-wing movements, to promote equal opportunities, safe workplaces and ethical trading and in doing so fight for social and economic justice at home and abroad. As the Chair, Steve Pryle, says in his introduction to the WBC history 'We should not forget that in 1979 there were 120 million trade union members worldwide and the numbers have grown to nearly 170 million. WBC is an innovative part of this international movement for economic and social justice' (Brown et al, 2016). In 1986 WBC began its 31-year relationship with Glastonbury; during that time, the business has developed and it has run bars at many events, it has promoted events as well as open its own pub and venue, The Bread and Roses in Clapham. For example, in 2010 WBC ran bars at 16 festivals, the Proms in the Park, summer events in Kenwood and Die Spiegel Tent as part of the Christmas Festival in Hyde Park. Its business model is simple, WBC is able to mobilise thousands of volunteers to manage and run the bars at events. All the volunteers are sympathetic to the core values of the organisation and sign up to its CSR objectives. Each of the volunteers is sponsored by a trade union or broadly left-wing campaigning organisation that wishes to raise money by providing the labour at the events WBC runs the bars. Rather than paying the individual WBC pays the sponsoring organisation for each hour the volunteer works; many groups send teams of workers and raise good money for their organisations. Each of the organisations is approved by the company to ensure that they are sympathetic with WBC CSR objectives. Over the last thirty years WBC has worked with tens of thousands of volunteers and in most the company mobilises a temporary volunteer workforce of about 3,000 . In this way WBC has contributed to a wider 
form of CSR by integrating its objectives with those of the volunteer organizations and creating greater value through supporting those individual organizations pursuit of CSR objectives. As an organisation mobilising vast numbers of temporary workers in a very public place it takes its responsibilities seriously and places great value in respecting its workers' rights, treating them fairly in a very challenging workplace, and ensuring that they can use their experience with WBC to progress their own careers. As the chair of the WBC, Steve Pryle, says 'It can be demanding work and servers have to keep motivated and cheerful in challenging conditions. On the other hand, taking in the music and the atmosphere of the festival is the fun side of volunteering' (Brown et al, 2016). The volunteer organisations campaign and promote CSR objectives in other work places or communities, for example; supporting the human rights and choice issues raised through the campaign to support Abortion Rights in Ireland; supporting Anti-Slavery International an organisation set up to help victims of trafficking; supporting the London Feminist Network an organisation set to give women a voice and to reclaim the streets to make them safe for women night and day; supporting GMB Yorkshire and North Derbyshire Young Members an organisation set up to promote trade union membership amongst young people as well as events to bring like-minded young people together to participate in campaigns and events like regional football tournaments for young people. In 1986 at the first Glastonbury there were 17 volunteer server groups - 30 years later there are now over 180 server groups supplying the workers for the WBC. Alongside CSR objectives being progressed through the volunteer groups the WBC directly supports trade union and labour movement groups at home and abroad. Based on its experience and commercial awareness it sets aside the capacity to directly fund trade union activity and campaigns as part of its integrated business plan to deliver its CRS objectives.

This is done in the light of running bars at festivals does not generate huge surpluses, ticket sales are unreliable, the weather fickle, the costs of the franchises to run bars are high and the logistics of running a business in a field are risky. However, the WBC has longstanding commitments to fund its own CSR programme of social change through labour and trade union movements; for example, WBC directly supports Banana Link (promoting ethical farming and trade in bananas and pineapples through, trade unions, workers' rights and the supply chain), Haiti Solidarity (promoting human rights, trade union rights and fighting poverty), National Garment Workers Federation of Bangladesh (promoting workers safety, trade unions, human rights and ethical supply chains for clothing in high street shops), Ethical Threads (supplying ethically sourced t-shirts for the music industry) and Greener Jobs Alliance (promoting environmental economic and education policy for workers and climate change awareness for trade unions).

Alongside these manifestations of CSR, the company has also been at the forefront of innovation as part of its CSR contribution to the industry. WBC has worked with its stakeholders, companies like Voodoo Group and Three Nations for many years and has built up levels of trust that has led to innovation, minimised risks and maximised commercial success with its partners in a challenging environment. It has led the development of dispensing drinks quickly to crowds, using multiple dispense units, which has massively reduced queues and frustration at bars which in turn improved the company's commercial success as a world leader. Through analysing how the bars operated WBC has optimised managing its bars to minimise the risks 
of crushing and improving crowd safety; particularly after the tragic events at the Roskilde Festival in Denmark in 2000 when nine people died and twenty-six were injured during a crush. ${ }^{\text {iii }}$

Working with technical specialists to learn about dispensing drinks rapidly WBC staff can pour 12 pints ( 1 pint UK measure) in 20 seconds. This has immeasurably changed the quality of service festival goers experience and the fun they have at events around the world. A small contribution to making life pleasant, the "worker enjoying the roses' and in the words of George Bernard Shaw some 'Counters of a more spiritual kind are needed, and some imagination and conscience to add to them as well' (Shaw, 1904).

The last element of WBC and it fulfilling its CSR responsibility relates directly to environmental stewardship. Over the last 30 years there has been increasing public and government pressure for organizations to minimize the harm they cause and reduce their environmental footprint. Even though WBC works with temporary events, some lasting only a day and others like Glastonbury several days, it has to meet all the requirements laid down by law and by the event promoters. It has to ensure that none of its operations contaminate or damage the land, that nonrecyclable waste is managed responsibly and that recyclable waste is recycled properly, for example using reusable/washable plastic pint glasses. The watch words for this part of the operation are - leave no trace.

In this section, the manifestations of WBC's CSR and its stakeholder relationships have been discussed in seven broad categories; how WBC was formed and that CSR is an integral part of its origins and governance, the relationship with its volunteers, the workers that pour the drinks, how the volunteer groups pursue CSR objectives through campaigning or the trade union movement, how WBC supports organizations that have CSR objectives, how working with stakeholders supports broad CSR objectives and finally how WBC has developed its environmental stewardship CSR aims.

Working with stakeholders and pursuing CSR objectives will be briefly explored through the work WBC has done for over 30 years with The Glastonbury Festival of Contemporary Arts.

\section{Glastonbury}

Glastonbury is one of WBC's stakeholders and the WBC is one of theirs. Using the UNIDO map of stakeholders both organizations share stakeholders and performance issues. Arguably each has a degree of dependence on the other which shifts over time.

For example, in the long-term risk management and planning lies with Glastonbury as the event gets closer to opening the risk management profile can change; for instance, if the weather rapidly deteriorates the individual suppliers to Glastonbury have to take greater responsibility for minimizing the risk.

Glastonbury and WBC share the government, employees, suppliers, future generations, effected communities, the environment, customers and investors as stakeholders. Political influence, reputation, risk management, market share, supply chains, efficiency, product stewardship, climate change, diversity, human rights, working conditions, responsible marketing and economic development are common 
economic, environmental and social performance issues for both Glastonbury and WBC.

In this sense, their overall objectives are closely related and arguably indivisible.

Not only does Glastonbury share the same stakeholders it also shares similar roots in ideas of social responsibility. Michael Eavis' Glastonbury manifesto puts forward the idea that 'Man is fast ruining his environment, he is suffering from the effects of pollution; from the neurosis brought about by a basically urban industrial society; from a lack of spirituality in his life; and a spiritual awakening' sentiments that underpin CSR objectives to protect the environment and promote the spiritual wellbeing of people - sentiments that resonate with WBC principles - and that people should have fun.

Since it started in 1970, Glastonbury has sought to pursue its CSR objectives in three broad ways, the first to ensure that the festival does not damage the farmland it uses so it places a very high value of environmental stewardship, to promote alternative ways of living as well as political engagement, it has also supported and promoted national and international campaign movements through ticket sale donations as well as involvement in the event, for example, CND, Greenpeace, Wateraid and Oxfam all NGOs making significant changes to many people's lives.

WBC started its involvement with Glastonbury in 1986 running five bars from $11 \mathrm{am}$ to $11 \mathrm{pm}$ from the Friday to the Sunday with 105 volunteers from 17 server organisations. In $2016 \mathrm{WBC}$ ran nine substantial bars around the arena some open until $3 \mathrm{am}$. One bar opens the week before to cater for the traders and staff setting up the event with the rest opening by the Wednesday before the event starting on Friday.

It now takes 10 times the number of staff it took in 1986, 1000 volunteers from 135 server organisations (Brown et al, 2016).

In the early days, the event was quite anarchic with the organisers just managing to get by without any major problems or harm being caused. The event has grown from having some 18,000 visitors in the early 1980 s to welcoming 135,000 paying visitors and up to 68,000 people working there now. The local government involvement has increased over the years, from the early days when there used to be breaches in the licensing conditions and lapses in security. These led to a serious review of the arrangements in place, finding them wanting and bringing in expertise from outside the original circle of organisers. In 2002 Glastonbury had to radically improve its site security and organisation to meet licensing requirements and reduce the fear of violence perpetrated by drug dealers and others.

Over time Glastonbury had to learn how minimise the harm it caused to its immediate surroundings, in part, this is an expression of CSR and is about how it sensibly engages with its community, has a proper traffic plan in place, employs local people, supports local fund raising and seen to contribute to meeting local needs by building affordable housing in the immediate area.

Arguably, there were moments in the past when there were real concerns whether the organisation was acting responsibility or not and able to manage the event successfully without people coming to harm. As a consequence of these concerns the expectations on the organisers from the local authority have increased and have been codified, in line with changing legislation, to include how the event should be managed responsibly. Responsibilities that might have been voluntary CSR in the past are now integrated into the event's management plan and have been agreed with the local authority and apply to all those involved in running the event. 
The plan recognises Glastonbury's place in history and covers the key objectives for running a safe and enjoyable event 'The Festival's popularity and influence is sustained by the vision behind it. In 1970 the founder set out to "host the best festival, rather than worry about making a profit". The Festival continues to provide significant support to both local organisations and main stream charities with Greenpeace, Oxfam and Water Aid among the principal beneficiaries. The Festival is planned by a small team that work throughout the year, this team grows in number preceding the event to cover the vast range of roles required to deliver the Festival.

Glastonbury Festival aims to continue to improve its entertainment for the wide variety of Festival goers while at the same time looking at its impact on the local community, environment and making incremental improvements year by year' (Mendip Council, 2016). The document then goes on to state how the organisation has integrated its relevant social responsibilities and how it intends to reduce the harm it might cause to site, its environment and the well-being of festival goers and workers.

As it has been argued in the past the relationship it has with $\mathrm{WBC}$, and other suppliers, shape the manner in which WBC realises some elements of its CSR in line with the event management plan; reinforcing the mutual interest and expectation in a delivering socially responsible, including spiritually uplifting, commercial activity.

The relationship with Glastonbury highlights three particular elements of CSR, the first is that organisations with mutual objectives and approaches can enjoy commercial successful relationships that combine CSR outcomes and secondly CSR can be voluntarily integrated in to the day to day activities of stakeholders sharing common objectives, people enjoying themselves in a safe environment. Thirdly CSR objectives can be codified and integrated through government action for example the festival management plan delivering CSR objectives; environmental stewardship, health and safety, alcohol licensing and the security of the site and visitors.

\section{Conclusions}

This is not a theoretical discussion on how CSR may develop over the coming years, it is not an attempt to discuss the various shades of CSR or the intricate relationships between stakeholder, shareholder and customers and their respective roles in the struggles between them. This is a discussion on how CSR can be shaped and integrated into the corporate world and deliver commercial success. It uses the example of a not for profit social enterprise that sells drink at major events and the relationship it has with its workers and others. It also uses the example of the way in which it works with Glastonbury Festival and examines three examples of how CSR can be integrated across organisations to deliver mutual CSR objectives. It does not claim that this approach would work for everyone - but it would argue that everyone should give these ideas a thought when looking at their CSR approaches in the future.

The first conclusion is that corporate responsibility is not new; it has existed ever since corporations could act irresponsibly. Debatably, the legislation allowing bodies to incorporate was set up to allow organisations to act irresponsibly because shareholder liability was limited to their investment not and did not cover the cost of rectifying any harm they might make. There were no advantages or any incentives for organisations to act responsibly. Not a good start. 
The next is that early economic theory suggests that corporation are amoral and that the profit and loss 'bottom line' is the only criteria to judge commercial success.

However, this is approach is challenged by early $20^{\text {th }}$ century entrepreneurs and thinkers when the Lever Brothers extended philanthropy and suggested that people should lead pleasant lives, be well educated and work in safe places. George Bernard Shaw reinforces this sense of well-being by saying that is not just the accounts that should be examined but that people should be spiritually uplifted by the commercial or municipal activity.

Corporate and individual choice are both important in defining how the organisation approaches CSR and its integration into the commercial activity; both WBC and Glastonbury had their origins shaped by a strong political motivation to inform, campaign and change people's lives either through the trade union movement or campaigning organisations like Greenpeace. They share a common language about CSR and what it should look like.

From the case studies both WBC and Glastonbury, referring back to Kinsey's three challenges, have engaged with their stakeholders consistently over time, for some over thirty years. They have built trust with their stakeholders to ensure that any initiatives are not dismissed as propaganda, again, a feature of time. And, out of necessity, worked together to deliver successful events as well as contribute to shared CSR objectives. They demonstrate that CSR objectives can be codified through local government legislation, shared and jointly and severally implemented; for example, the Glastonbury Festival event management plan. They help to explain how some CSR objectives can become integrated into corporate activity as a consequence of media and public pressure for example improving environmental stewardship, promoting responsible drinking and ensuring crowd safety.

And finally, perhaps, rather than seeing CSR as a sterile extension of amoral corporate activity it should be seen as an increasingly more integrated function of corporate activity. Organizations should be encouraged to celebrate reducing harm, improving work conditions, protecting human rights and contributing to peoples' well-being by doing things that are spiritually uplifting. Any future for CSR and its integration into day to day activity would do well to reflect on the ideas promoted in a speech given over 100 years ago that 'The worker must have bread, but she must have roses, too.' - and that exploring the spiritual or moral dimensions could contribute to creating value in organisations for all stakeholders involved. Over forty years ago the Glastonbury Manifesto called for a better way to do business, lessen the environmental impact and time for people to celebrate their lives - what will the next forty years deliver in making lives better and reducing the harm we experience.

\section{Bibliography}

Bailey, J. (2013) Glastonbury, The Complete Story of the Festival, Halsgrove.

Brondoni, S. M. (2003). Network Culture, Performance \& Corporate Responsibility. Symphonya. Emerging Issues in Management (symphonya.unimib.it), (1), 8-24. http://dx.doi.org/0.4468/2003.1.02brondoni

Brondoni, S. M. (2014). Global Capitalism and Sustainable Growth. From Global Products to Network Globalisation. Symphonya. Emerging Issues in Management (symphonya.unimib.it), (1), $10-31$. 
http://dx.doi.org/10.4468/2014.1.02brondoni

Brown, M., Ferguson, K., Pike, A., Pryle, S., Weaver, A.,Brady, R. Budds, R., Gleeson, G. \& Pollen, C. (2016). Celebrating 30 Years of Fund Raising, Workers Beer Co. 30 Years, Thirst Amongst Equals. Battersea and Wandsworth Trades Union Council.

Browne, J., Nuttall, R., (2013) Beyond corporate social responsibility: Integrated external engagement.

McKinsey and Company.

Freeman, R.E., Buck, A.C., Parmar, B. (2001) Stakeholder Theory and 'The Corporate Objective Revisted' in Organization Science, Volume 15, number 3. May - June 2004. https://doi.org/10.1287/orsc.1040.0066

Glastonbury Festival Events Ltd 2017 (2016), Event Management Planning, Mendip [online] available at http://www.mendip.gov.uk/CHttpHandler.ashx?id=16325\&p=0 $\quad\left(\right.$ accessed $13^{\text {th }}$ November 2017).

Jenkins, R. (2005). Globalization, corporate social responsibility and poverty. International affairs, 81(3), 525-540.

https://doi.org/10.1111/j.1468-2346.2005.00467.x

Lins, K. V., Servaes, H., \& Tamayo, A. (2017). Social capital, trust, and firm performance: The value of corporate social responsibility during the financial crisis. The Journal of Finance.

https://doi.org/10.1111/jofi.12505

Musso, F., \& Risso, M. (2006). CSR within large retailers' international supply chains. Symphonya. Emerging Issues in Management (symphonya.unimib.it), (1).

http://dx.doi.org/10.4468/2006.1.06musso.risso

Pegg, S., \& Zabbey, N. (2013). Oil and water: the Bodo spills and the destruction of traditional livelihood structures in the Niger Delta. Community Development Journal, 48(3), 391-405.

https://doi.org/10.1093/cdj/bst021

Risso, M. (2012). Exploring Partnerships for Social Innovation. Symphonya. Emerging Issues in Management (symphonya.unimib.it), (2), 26.

http://dx.doi.org/10.4468/2012.2.03risso

Ruggie, J. G. (2017). Corporate Social Responsibility and the Global Compact. in Mcintosh, M. (ed.), Business, Capitalism and Corporate Citizenship: A Collection of Seminal Essays. Greenleaf Publishing.

Shaw, G.B. (1904) The Common Sense of Municipal Trading. Westminster: Archibald Constable and Co., Ltd.

Tombs, S, and Whyte, D. (2010) 'Crime, harm and corporate power' in Muncie, J, Talbot, D and Walters, R. (eds) Crime Local and Global, Cullompton, Willan Publishing/The Open University.United Nations Industrial Development Organisation (UNIDO) (2013), What is CSR [online] available at http://www.unido.org/csr/o72054.html (accessed $7^{\text {th }}$ November 2017).

\section{Notes}

${ }^{i}$ See https://www.icij.org/investigations/paradise-papers/ Accessed 13 ${ }^{\text {th }}$ Nov 2017

ii see https://link.springer.com/chapter/10.1057\%2F9780230610125 7 Accessed $13^{\text {th }}$ Nov 2017

iii Reported in Rolling Stone Magazine see http://www.rollingstone.com/music/news/nine-dead-atpearl-jam-concert-20000817 Accessed $13^{\text {th }}$. November 2017 